Boston University School of Law

Scholarly Commons at Boston University School of Law

Faculty Scholarship

$12-2018$

\title{
Comment on 'Error and Regulatory Risk in Financial Institution Regulation'
}

Keith N. Hylton

Boston University School of Law

Follow this and additional works at: https://scholarship.law.bu.edu/faculty_scholarship

Part of the Banking and Finance Law Commons, and the Law and Economics Commons

\section{Recommended Citation}

Keith N. Hylton, Comment on 'Error and Regulatory Risk in Financial Institution Regulation', in No. 18-29 Boston University School of Law, Law and Economics Research Paper (2018).

Available at: https://scholarship.law.bu.edu/faculty_scholarship/551

This Article is brought to you for free and open access by Scholarly Commons at Boston University School of Law. It has been accepted for inclusion in Faculty Scholarship by an authorized administrator of Scholarly Commons at Boston University School of Law. For more information, please contact lawlessa@bu.edu. 


\title{
BU School of Law
}

\section{COMMENT ON “ERROR AND REGULATORY RISK IN FINANCIAL INSTITUTION REGULATION”}

\author{
Boston University School of Law \\ Law \& Economics Series Paper No. 18-29
}

December 2018

Keith N. Hylton

Boston University School of Law 


\title{
Comment on "Error and Regulatory Risk in Financial Institution Regulation"
}

\author{
Keith N. Hylton*
}

I agree with just about everything Jonathan Macey (2017) says in his symposium contribution. His claim that bureaucratic tendencies toward regularity—specifically, treating like cases alike-generate errors in categorization seems appropriate to me. His explanations of the pathologies in financial regulation should fall in the category of essential or required reading for anyone who chooses to write on the topic. Where I differ from Macey is in the choice of framework, or perspective from which to view the pathologies. Whereas Macey adopts an "error cost" framework, which is clearly appropriate for this symposium, I would build explicitly on a "public choice" framework. ${ }^{1}$

Margaret Thatcher famously said that "Europe was created by history. America was created by philosophy." One could unpack Thatcher's statement further by saying that Europe was created by accidents, catastrophes, and wars, whereas America, and particularly the American Constitution, developed at least in outline form from a wellconsidered design (see, e.g., The Federalist Papers). ${ }^{2}$

* William Fairfield Warren Distinguished Professor, Boston University; Professor of Law, Boston University School of Law. I thank Jack Beermann for helpful comments.

${ }^{1}$ Public choice can be described as the application of economics to political science. I refer generally to the theory that government actors engage in self-interested, utilitymaximizing behavior. On public choice theory, see Mueller (1989) and Niskanen (1971). Although I distinguish the error-cost model adopted by Macey from the public choice model, the two models are by no means mutually exclusive. Moreover, Macey has contributed substantially to the public choice literature himself (see, e.g., Macey 1988). For a critique of Macey's public choice arguments, see Beermann (1991).

${ }^{2}$ Obviously, one could quibble that the US Constitution itself is the result of history (wars, catastrophes, accidents, trial and error). But even a casual reader of a found- 
One can offer a similar division in explaining a particular regulatory framework: it is either a creation of history or of philosophyor some mixture of both. Macey's thesis that bureaucratic tendencies toward order generate regulatory pathologies suggests a vision of bureaucrats who at least try to play the role of philosophers or "intelligent designers" of regulation. I would start with a very different view of regulatory bureaucrats.

I believe history carries much more weight than philosophy in accounting for the shape of most regulatory frameworks in finance. Financial regulation responds to accidents and catastrophes-such as the Great Recession of 2008. In the wake of these accidents, legislatures respond with new regulations, and factions consisting largely of incumbent pressure groups move in with versions of reform suitable to their interests. The result is a legislative "solution" that often fails to resolve the pathologies that caused the catastrophes because so many compromises and carve-outs have had to be included to satisfy the incumbent factions. The most powerful interest groups typically do not lose their advantages over rivals at the end of the reform process and often emerge from the ashes of reform with even greater competitive advantages. The groups that received the largest subsidies from the state before the catastrophe continue to receive their subsidies after the reform.

Increasingly, the statutes that emerge from regulatory reform introduce a new regulatory infrastructure as well. The statutes generate new rules that firms must follow to gain regulatory approval or to avoid punishment. In the wake of the Dodd-Frank Wall Street Reform and Consumer Protection Act (Dodd-Frank), banks have had to hire numerous employees (private bureaucrats) to help them figure out how to comply with the many rules embedded in the statute. Modern reform statutes increasingly generate agencies that must be staffed by government bureaucrats and that are charged with producing more rules. For example, the Consumer Financial Protection Bureau, created by Dodd-Frank, now employs nearly 2,000 people, and the agency worked diligently, until the change in administration in 2017, to develop new rules to regulate lenders. These agencies are overseen ultimately by courts, but they often work initially to create a barrier between the regulated parties and the courts.

Stepping a bit further into generality, in the wake of financial catastrophes, reform legislation sets initial conditions for new law that will regulate the finance industry. This new law often will be a "negotiated product" resulting from deals made among legislators and incumbent

ing document such as The Federalist Papers would be astounded by the depth of analysis-of economics, of history, of alternative institutions-reflected in the work. 
factions (large firms, regulatory pressure groups). From these initial conditions, bureaucratic action can either exacerbate the inefficiencies built into the initial bargain or mitigate the inefficiencies. Whether bureaucratic actions will mitigate or exacerbate the inefficiencies depends, in turn, on other factors: whether the sitting administration is committed to addressing the inefficiencies (although very often the administration will introduce new inefficiencies or biases) and the extent to which the courts oversee the regulatory regime. As a general rule, where courts play a strong and direct role in administering the statute, such as the Sherman Antitrust Act of 1890 (Sherman Act), the inefficiencies in the initial design tend to be mitigated through court review. ${ }^{3}$ Conversely, where courts are somewhat removed from administration because of the existence of an administrative agency burdened with enforcing an enormous regulatory statute (e.g., health-care regulation), there is a greater likelihood that bureaucratic action will exacerbate inefficiencies built into the framework from the start.

I just offered the Sherman Act as an example because it is a regulatory statute with such a thin set of rules at its base that courts have been left to administer the statute with virtually no direct administrative or bureaucratic input by executive-branch agents. The executivebranch agents who help to administer the Sherman Act do so only as enforcers-that is, essentially as plaintiffs who come to court and attempt to persuade the court to apply or to change the law in order to advantage the enforcer. Sherman Act enforcers, however, play no direct role in the creation or interpretation of the law. The result has been a consistent move toward relatively simple and discretionary rules that have tended to be efficient. The general trend of antitrust law has been away from per se prohibitions and toward "rule of reason" tests that enable courts to consider the efficiency of a particular practice before deciding whether it should be declared unlawful under the statute.

Macey's contribution addresses regulation within an administrative or bureaucratic framework-in contrast to the courts. This is an appropriate focus, in this case, because it is consistent with the nature of financial regulation. Unlike the Sherman Act example, the statutes Macey examines are mostly elaborated and developed through direct bureaucratic involvement. Agency officials working on financial regulation generally develop and explicate statutory provisions-the most famous example of which is the Volcker rule, which involves hundreds of pages of bureaucratic law development.

${ }^{3}$ For an elaboration of this claim about the relationship between statute and common law, though in the context of federal labor law, see Hylton (1993, 1996). 
Within the agency framework Macey studies, we observe the errors he describes and correctly attributes to bureaucratic action. The tendency toward regularity — of treating like cases alike-I would attribute to the possibility and risk of court review rather than a general tendency or desire for order among bureaucrats. I think bureaucrats seek orderly explanations for their actions because those actions eventually will be exposed to judicial scrutiny. If those actions were never to be exposed to judicial scrutiny, the bureaucrats would care a lot less about generating the appearance of order. The other tendency Macey attributes to bureaucrats, which is to avoid the costs of erroneous regulatory inaction, reflects the asymmetric political costs of action and inaction. Erroneous action can always be defended ex post, often by referring to the horrible events that might have resulted without action. Erroneous inaction, however, always leaves the bureaucrat exposed to charges that he failed to act appropriately and in time. ${ }^{4}$ Such charges are often politically motivated.

Macey offers several examples to support his thesis of bureaucratic error. One is the "systemically important financial institution" (SIFI) status categorization for firms administered by the Financial Stability Oversight Council (FSOC), an agency created by Dodd-Frank. The SIFI categorization has been imposed on firms too aggressively, Macey argues, inappropriately burdening some firms with the status (e.g., MetLife). Although I agree with Macey's description of the process as prone to error, I am equally impressed by the competitive effects of the FSOC's actions. The SIFI designation imposes costly regulatory obligations that clearly favor the largest firms within the industry. Firms directly below achieving SIFI status have no incentive to expand into the status. Firms with the status have incentives to increase in scale, because by increasing they can reduce the unit cost of regulation.

The same pattern holds for Dodd-Frank generally. The regulatory costs of the statute have advantaged larger banks, because they can spread the fixed costs of regulatory compliance over a much larger revenue base. At the same time, the regulatory costs have pushed a substantial share of the smaller, community-oriented banks out of business (or into forced consolidations) and throttled the entry of new community banks.

The Community Reinvestment Act shows the same pattern (see Macey and Miller 1993; Hylton and Rougeau 1996). The statute aims

\footnotetext{
${ }^{4}$ It is important, in this argument, that the bureaucrat's actions are publicly observable and monitored by hostile political factions. If the bureaucrat's actions were not observable, then inaction would be an attractive option because it would allow the bureaucrat to enjoy a more leisurely work environment. When, for example, public enforcement agents are not consistently monitored, the problem of motivating them to enforce the law becomes a central concern (see Becker and Stigler 1974).
} 
to promote investment in economically decaying inner cities. Large banks have found it relatively easy to comply compared with their smaller rivals. The interesting feature here is that the smaller rivals most burdened by the statute often consist of minority-owned banks that entered the industry with the aim to serve businesses in the predominantly minority communities of inner cities.

Sometimes regulatory errors are apparent, but they remain in place because the cost of correction for large incumbents is too high. For this, probably the best illustration is the work of credit rating agencies with respect to mortgage-backed securities. One of the questions generated by the 2008 banking crisis is why the credit rating agencies moved in parallel fashion by awarding high credit ratings to mortgage-backed securities long after evidence emerged suggesting that a downgrade would be appropriate (for an insightful discussion, see Hill [2010]). One obvious possible explanation is that the credit rating agencies did not really compete against each other, suggesting that the high credit ratings given to mortgage-backed securities resulted from tacit collusion. However, as Macey makes clear, large banks had "herded" into these securities because of the erroneously high credit ratings. The result was an equilibrium in which banks and credit rating agencies joined in a rational disbelief of bad news. Too much was at stake for the credit rating agencies to rationally update their assessments and consequently downgrade the securities.

The general pattern is simple: large banks manage the statutory reform process so that it produces a regulatory framework that advantages them relative to their smaller rivals. The result is that the banking industry moves toward greater concentration, increasing the degree of financial risk. Substantial subsidies, such as the one provided by federal deposit insurance (coupled with inefficient pricing of the insurance), remain in place despite numerous rounds of reform.

In sum, I am in full agreement with Macey on the processes and tendencies of bureaucratic error. However, I would identify the source of those tendencies within incentives created, often deliberately, by participants in the statutory reform process.

\section{R E F E R E N C E S}

Becker, Gary S., and George J. Stigler. 1974. "Law Enforcement, Malfeasance, and Compensation of Enforcers." Lournal of Legal Studies 3:1-18.

Beermann, Jack M. 1991. "Interest Group Politics and Judicial Behavior: Macey's Public Choice." Notre Dame Law Review 67: 183-230. 
Hill, Claire A. 2010. "Why Did Rating Agencies Do Such a Bad Job Rating Subprime Securities?" University of Pittsburgh Law Review 71:585-608.

Hylton, Keith N. 1993. "Efficiency and Labor Law." Northwestern University Law Review 87:471-522.

Hylton, Keith N. 1996. "A Theory of Minimum Contract Terms with Implications for Labor Law." Texas Law Review 74:1741-82.

Hylton, Keith N., and Vincent D. Rougeau. 1996. "Lending Discrimination: Economic Theory, Econometric Evidence, and the Community Reinvestment Act." Georgetown Law Journal 85:237-94.

Macey, Jonathan. 2017. "Error and Regulatory Risk in Financial Institution Regulation." Supreme Court Economic Review 25:XXXXXX.

Macey, Jonathan R. 1988. "Transaction Costs and the Normative Elements of the Public Choice Model: An Application to Constitutional Theory." Virginia Law Review 74:471-518.

Macey, Jonathan R., and Geoffrey P. Miller. 1993. "The Community Reinvestment Act: An Economic Analysis." Virginia Law Review 79:291-348.

Mueller, Dennis C. 1989. Public Choice II, 2nd ed. Cambridge: Cambridge University Press.

Niskanen, William A., Jr. 1971. Bureaucracy and Representative Government. Chicago: Aldine-Atherton. 